\title{
東京都古書籍商業協同組合創立90周年記念 日本の古本屋シンポジウム
}

「滅亡か, 復権か一大規模デジタル化時代と本の可能性」

\begin{tabular}{|c|c|}
\hline & 一橋記念講堂（東京） \\
\hline 凗 & 東京都古書籍商業協同組合 \\
\hline 協 賛 & 全国古書籍商組合連合会, アカデミック・リソース・ガイド株式会社 \\
\hline 協 & NPO法人横浜コミュニティデザイン•ラボ \\
\hline
\end{tabular}

情報管理５3(3), 165-168, doi: 10.1241/johokanri.53.165 (http://dx.doi.org/10.1241/johokanri.53.165)

東京都古書籍商業協同組合は創立90周年を記念し， 2010年4月14日，国立情報学研究所において書籍とデ ジタル化に関するシンポジウム「滅亡か，復権か一 大規模デジタル化時代と本の可能性」を行った。定 員の 200 人を大幅に上回る参加申し込みがあり，抽選 で参加者を絞ったほどの盛況であった。

また，当日の会場の映像はインターネット上で生 放送 (ストリーム配信)され1)，閲覧者からツイッター を通じて寄せられた質問2) にパネリストが回答する など，リアルタイムWebを活用したシンポジウムで あった。

以下に，その内容を簡単に報告する。

\section{1. 挨拶}

東京都古書籍商業協同組合理事長・小沼良成氏よ り開会の挨拶があった。古書組合の歴史を戦前より 振り返り，インターネットとデジタル化の時代を迎 えて，ネット上で古書の検索ができるサイト「日本 の古本屋」の運営を始めたこと，その開設にあたつ ては大日本印刷や三菱総研の協力を得たこと，そし て現在ではこのサイトで管理する目録が国立情報 学研究所 (National Institute of Informatics: NII) の Webcat Plusにも揭載されていることなどが紹介され た。

\section{2. 講演 (1) 長尾真氏}

国立国会図書館（National Diet Library: NDL）・長 尾真館長が「ディジタル書籍の時代と古書」と題して， NDLにおける図書のデジタル化の現状について講演 した。

まずNDLにおけるデジタル化は現在，

・国会議事録（テキストデータ）・帝国議会議事

録 (画像) ・貴重書画像データベース・近代デジ タルライブラリー・電子展示会

等が公開されている。

今後は127億円の補正予算を利用して，1968年ま でに発行された図書・著名な雑誌・博士論文・官報・ 古典籍等約 90 万冊を 2 年間でデジタル化する予定であ る。デジタル化された書籍はイメージデータで著作 権処理が済んだもののみ公開する。ただし館内端末 では著作権未処理の資料も見られる。著作権者が不 明である孤児著作物については，文化庁の裁定を受 けた後に公開する。

書籍以外の新しいメディア文化財として，写真・ 絵画，三次元物体・遺跡，無形文化財（演説や語り）， 歌謡・音楽，インターネット上の情報等，本以外の 情報メディアのデジタル保存についても広い範囲を 考えなければならない。

デジタル情報の保存における課題には，ひとつに はメタデータの問題があり，データの国際的標準 フォーマットの設定が必要だ。また，情報の保存媒 
体について，オフライン媒体での保存は媒体変質・ 再生機器がなくなる等の問題がある一方，オンライ ン媒体では，数年ごとに機器の変更とデータの移行 を行わねばならず，いずれにしても膨大な費用がか かる。何百年も変化しないオフライン記憶媒体の開 発が必須である。

古書との関係では，デジタルのコピーでなく実物 を見たい／入手したいという欲求もあるので，例え ば，古書店の在庫リストをデータベース化し，出版 物情報と古書情報を一度に検索できるようなシステ ムや，情報と実物をシームレスにリンクすることな どが考えられる。

質疑応答では「NDLの書籍のデジタル化とテキス トデータの公開について，出版界が慎重であること は大事だが，国会図書館内のみでの閲覧は地方在住 者には利用しづらい」という意見に対し，「デジタル 化してしまうと，世界中どこへも持っていける。利 用しない手はない。人類の知的資産は誰にでも使え るべきであり，それを整備する必要がある。ただ， 何も配慮しないと出版社・著者が生きていけないの で，オンラインでの利用者には国会図書館に来る交 通費代くらいを支払ってもらって出版界に戻すシス テムにするなど，ビジネスモデルを作り，著者・出 版社と利用者がWin-Winになるようにしたい」とのこ とだった。

\section{3. 講演 (2) 森野鉄治氏}

ここ数年で出版流通に関係する企業を傘下に収め， 特に昨年のブックオフ買収が話題になった，大日本 印刷株式会社（DNP）の森野鉄治常務取締役が「出 版印刷業界の再編」について講演した。

まずは大日本印刷の業態を説明した。出版印刷は 事業の1割で，広告等の商業印刷やCカード等のビ ジネス関連印刷，印刷から派生した電子ペーパーな どの電子部品も大きな割合を占める。印刷業はブラ ンドを持っておらず，これまで出版業界の中でも裏 方に徹していたが，この变革の時期にビジネスモデ
ルとして印刷技術を適用するだけでは対応できなく なってきた。そんな時代のDNPのミッションを，「出 版エンジニアリング」に置き，知の再生産に寄与す ることを目指している。出版エンジニアリングのコ ンセプトは，ハイブリッド出版のプラットフォーム を作ることである。

2006年より，デジタル・ダウンロードの企業や出 版，図書館流通等サプライチェーンを傘下に収めて きた。2009年のブックオフの買収も，その流れの中 にある。

重視しているテーマは次の3点である。

\section{(1) 返本率の改善}

40\%の返本率のロスを，エンジニアリングによっ て解決できないか。

（2）デジタルを含むメディア制作コストの削減

Forbesのデジタル部門は，デジタル化して7年で ようやく黒字化したと聞いた。ネットの情報はタダ， という利用者の意識から，なかなか課金ができない。

デジタル化のコストを安くすることで黒字転換に 貢献できないか。現在印刷工程はほとんどデジタル で進行しており，印刷データからデジタル出版する ことはほとんどコストがかからない。紙の印刷物と デジタル出版のハイブリッド出版にすれば「デジタ ル化」の費用は最低限にできる。ただ，すでに出版 された物のデジタル化は課題だ。

\section{（3）販売機会の拡大}

M (美術館) L (図書館) A (文書館) と言われるが， アナログの時代には線引きがあったが，文化財を扱 うという意味ではデジタルの時代にはシームレスに なってきた。売る場・出会う場もシームレスになり， 本の販売機会も拡大する。

また，新刊書店は委託販売制度・再販制度のなかで， マーケティングを書籍取次業者に任せて配本された 書籍を販売してきた。一方古書店は，直接顧客を見 て仕入れ，值付けの判断もするという目利きであり， 本来のマーケティングは実は古書店が一番進んでい る。本当のビジネスモデルは古書店にあるのではと 
期待している。

\section{4. 講演 (3) 高野明彦氏}

NIIの高野明彦教授は，自身がこれまで開発してき た検索システムを順に紹介しながら，検索サービス に求められるものについて講演した。

(1) Webcat Plus <http://webcatplus.nii.ac.jp/>

大学図書館の蔵書，1,300万冊のメタデータ・デー タベース。

(2) $\mathrm{JINBOU}<$ http://jimbou.info/>

神保町の古書店をひとつの図書館のように検索し， 各古書店のオンライン書店へリンクする，バーチャ ルな神保町。神保町の古書店・中野書店から相談を 受けて構築し，「日本の古本屋」に提供しているデー タを預かって使う。古書店の店舗システムも合わせ て提供した。

（3）文化遺産オンライン <http://bunka.nii.ac.jp/>

文化庁の運営だが作成はNII。1万数千枚の文化財 の写真のデータベース。全国の美術館・博物館から 提供されたデータを用い，検索システムには「想一 IMAGINE」を使っている。

\section{（4）渋沢栄一記念財団 実業史錦絵絵引 $<$ http://ebiki.jp/>}

字引ならぬ，絵から検索する「絵引」。風俗錦絵の 中にそれぞれの事物の説明を埋め込み，また関連情 報を一覧できる。

\section{5.パネルディスカッション}

パネルディスカッションは，森野鉄治氏，高野明 彦氏，中野書店・中野智之氏，司会は河野書店・河 野高孝氏にて行われた。さまざまな発言が縦横に交 わされたので，特にこれからの書籍流通を予測させ るような質疑について，かいつまんで紹介する。

$\mathrm{Q}$ ：どうして印刷会社がプラットフォームを作ること にしたのか。

（森野氏）メディアを作る人も売る人も一人の人間が できるようになり，専業の境目がなくなるのがデジ

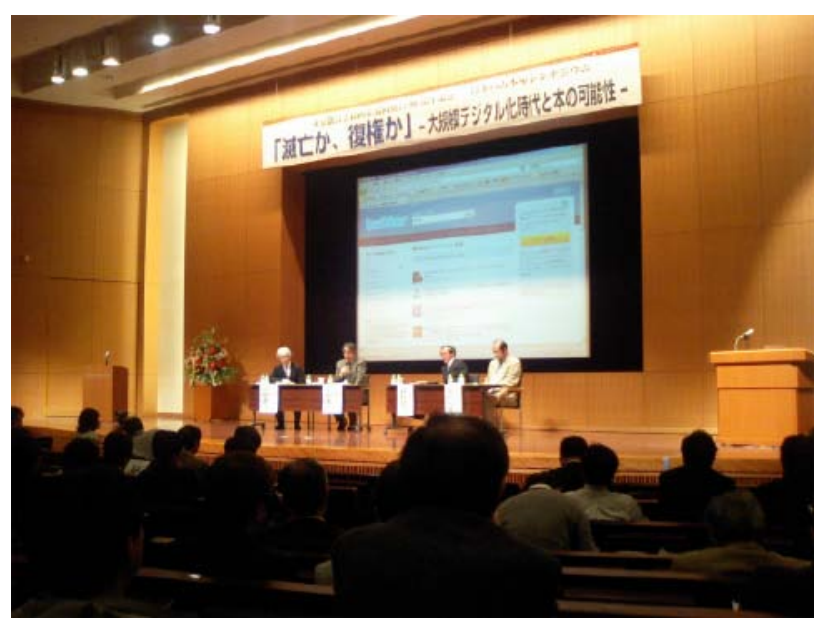

タルの時代である。

書店・図書館・教室等，情報が消費される現場で 同時に情報が作り出されている。

オープンなシステムで，プライベートな「本棚」 を準備している。例えば携帯電話のアドレス帳や， 読んだ本・聴いた音楽など，リストこそが「自分ら しさ」の表現である。リストを管理し，それを眺め ることで自分のよく聞く音楽・読んだことを忘れて いた本など自分自身を発見できる，リアルであると 同時にバーチャルである「本棚」を作る。

（高野氏）GoogleやAmazonなど米国発のビジネスモ デルに席巻されているばかりでなく，おもしろいビ ジネスが日本の中からも出てくることを期待してい たが，なかなか動きが悪く，ビジネスにつながらな かった。森野氏が動き始めたことで，日本でもそう いう動きが出てきたことはうれしい。

NIIは，インフラ・公共材として，情報資源を社会 に届けたい。おもしろいビジネスをやろうとしてい る人に対して有用なツールを提供したい。

MLA連携という話が出たが，MもLもAもあまり連 携について考えていない。何をしたらいいかわから ない，ということかも知れない。だから，Mにもしに もAにもあまり思い入れのない自分たちが外から助言 できたらいい。森野構想がそこまで広がっていくと いい，と期待している。

$\mathrm{Q}$ : デジタル化の行き着く先は，知の生産の仕組みも 
変わっていくのではないか。今見ているよりも違つ た局面はあるのか。

（高野氏）学術ジャーナルは10年前から電子化が進ん でいた。すでに，電子版のない雑誌は生き残ってい ない。当初は紙の雑誌とデジタルが抱き合わせ販売 されていたが，今は論文単位で支払う購読モデルに なってきている。出版の単位が小さくなってきてお り，ユーザは，読みたい論文だけを買いたいと思っ ている。

本も，知識を発信する単位が変わってくる。一部 分でもちゃんと役に立つものしか生き残れない。

Googleのページランクのような，ある意味「人気 投票」で人気のあるサイトが上に表示されるような 検索では，個人が本当に必要な情報を見つけること はできない。

見つけやすい形に知識が再編集されれば，過去の 知識にも日が当たるようになるのではないか。 $\mathrm{Q}$ ：デジタル時代のアナログの本の優位性は ? （高野氏）自分は，じっくり読むのは紙の本だが，参 照先はデジタルがいい。紙の本がデジタルによって 活きるようなコンパニオンなシステムができるとよ い。むしろ，デジタル書籍が単に紙の本を電子に置 き換えただけでは先がないだろう。デジタル書籍な らではの利点が出てきたときにデジタルがブレーク するし，そのときにアナログの新しい使い方も見え てくるだろう。

（森野氏）日経新聞が，アナログ+デジタルのビジネ
スを始めたが，アナログの一覧性のよさとデジタル の検索性のよさをバンドルした方法がいい。

現在のビジネスモデルと委託再販制の中で，出版 業界全体の同意は難しくても，成功モデルがあれば 新しいビジネスモデルに乗ってもらえるのではない か。

最初からデジタルファースト・デジタルエンドの 世代は新しい感覚を持つかもしれないが，今後20〜 30年はアナログとデジタルが並存するのではない か。新しいビジネスモデルが，2兆円産業と言われる 出版業界を3兆円にも4兆円にもする価値を生み出せ るのではないか。

\section{6. 感想}

シンポジウムのタイトルに「滅亡か，復権か」と あるように，紙の本と電子書籍はこれまで「紙か， デジタルか」の二者択一で語られることが多かった。 だが，このシンポジウムの中では紙の良さ，デジタ ルの便利さの双方を認め，双方をつなぐインターネッ トや検索の技術や，紙とデジタルの書籍を両方出版 するハイブリッド出版というビジネスモデルの提案 がなされたことが新鮮であった。

今年は，日本でもKindleやiPadなどの電子書籍端末 の発売が予定されており「電子書籍元年」とも言わ れている。書籍流通が今後どのように变化していく のかを注視したい。

(『情報管理』編集事務局)

\section{参考文献}

1) VideoPlanning. "VideoPlanning on USTREAM". USTREAM. http://www.ustream.tv/channel/videoplanning, (accessed 2010-04-27).

2) arg. “Togetter - まとめ「日本の古本屋シンポジウム「滅亡か， 復権か」」”. Togetter. http://togetter.com/ li/15237, (accessed 2010-04-27). 